Gomes Cordeiro, Pedro Miguel; Couceiro Figueira, Ana Paula; da Silva, José Tomás; Matos, Lennia School Motivation Questionnaire for the Portuguese Population: Structure and Psychometric Studies The Spanish Journal of Psychology, vol. 15, núm. 3, 2012, pp. 1441-1455

Universidad Complutense de Madrid

Madrid, España

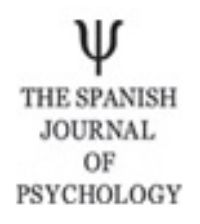

The Spanish Journal of Psychology, ISSN (Printed Version): 1138-7416 psyjour@sis.ucm.es Universidad Complutense de Madrid España

How to cite $\mid$ Complete issue $\mid$ More information about this article $\mid$ Journal's homepage 


\title{
School Motivation Questionnaire for the Portuguese Population: Structure and Psychometric Studies
}

\author{
Pedro Miguel Gomes Cordeiro ${ }^{1}$, Ana Paula Couceiro Figueira ${ }^{1}$, \\ José Tomás da Silva ${ }^{1}$, and Lennia Matos ${ }^{2}$ \\ ${ }^{1}$ Universidade de Coimbra (Portugal) \\ ${ }^{2}$ Universidad Peruana de Ciencias Aplicadas (Peru)
}

It is presented the structure and psychometric studies of the "School Motivation Questionnaire". The SMQ is a self-report questionnaire with 101 items, organized in sixteen scales that measure the students' goal orientations, the perceived classroom goal structures, the perceived teacher's autonomy support and the use of learning strategies. Twelve scales are adapted from the "Learning Climate Questionnaire", "Perceptions of Instrumentality" and "Cuestionário a Estudiantes". Four scales and five additional items are created new. The psychometric studies rely on a convenience sample consisting of $9^{\text {th }}$ and $12^{\text {th }}$ grade students $(N=485)$ of Portuguese schools. The factorial and construct validity, verified through several exploratory factorial analyses to the data, presents a final solution of six factors, labelled Strategies (F1), Teacher Extrinsic Goals (F2), Student Extrinsic Goals, Externally Regulated (F3) Teacher Intrinsic Goals (F4), Student Extrinsic Goals, Internally Regulated (F5), and Student Intrinsic Goals (F6). The six-factor solution explains a significant variance of the scale results (53.95\%). Good coefficients of internal consistency are obtained for all factors, never below (.858; F6). In sum there is strong evidence to support the multi-dimensionality of SMQ, upholding that the data obtained is exploratory and applies for future validation studies.

Keywords: theories of achievement motivation, "School Motivation Questionnaire", psychometric studies, perceived instrumentality.

\begin{abstract}
Se presenta la estructura y los estudios psicométricos del "Cuestionario de Motivación Escolar". El CME es un cuestionario de auto informe con 101 ítems, organizados en dieciséis escalas que miden las orientaciones de las metas de los estudiantes, la percepción de las estructuras de las metas de clase, las percepciones del apoyo del profesor a la autonomía y el uso de estrategias de aprendizaje. Doce escalas son una adaptación del "Learning Climate Questionnaire", "Perceptions of Instrumentality" y "Cuestionario a Estudiantes". Cuatro escalas y cinco frases adicionales se crearon para este estudio. Los estudios psicométricos se basan en una muestra de conveniencia compuesta por estudiantes de los grados 9 y $12(N=485)$ de las escuelas portuguesas. La validez factorial y la construcción ha sido verificada a través de varios análisis factoriales exploratorios de los datos, y presenta una solución definitiva de seis factores, siendo Estrategias ( $F 1$ ), Metas extrínsecas de los docentes (F2), Metas extrínsecas de los estudiantes, reguladas externamente (F3), Metas intrínsecas de los docentes (F4), Metas extrínsecas de los estudiantes ,reguladas internamente (F5), y Metas intrínsecas de los estudiantes (F6). La solución de seis factores explica una variación significativa de los resultados de la escala $(53,95 \%)$. Se encontraron buenos coeficientes de consistencia interna para todos los factores, nunca por debajo de (.858; F6). En suma, hay una fuerte evidencia para apoyar la multidimensionalidad del CME. Estos resultados son exploratorios y servirán como una base para estudios de validación posteriores.

Palabras clave: teorías de la motivación de logro, "Cuestionario de Motivación Escolar", estudios psicométricos, instrumentalidad percibida.
\end{abstract}

Correspondence concerning this article should be addressed to Ana Paula Couceiro Figueira. Faculdade de Psicologia e de Ciências da Educação, Universidade de Coimbra. Rua do Colégio Novo, Apart. 6153, 3001-802 Coimbra (Portugal). E-mail: apcouceiro@fpce.uc.pt 
The understanding of "how" and "why" students learn and do their best at school met remarkable developments over the past decades (Perry, Turner, \& Meyer, 2006). The paradigm shift that occurred within the Psychology of Motivation left behind the dominance of global, organismic theories of motivation in favour of more specific explanations of motivational phenomena, typical of the new born "mini-theories" or "process theories of motivation" (Perry et al., 2006). One motivational phenomenon that got the most empirical and theoretical productionwas the academic achievement motivation. The conceptual grid proposed, although still imprisoned by motivational explanations heavily focused on the characteristics of students, had the merit of expanding the motivational analysis to situational aspects of the learning environment, analysing how do they influence the quality of students' motivation, learning and academic achievement (Deci \& Ryan, 2000; Lens \& Rand, 1997).

Among the most relevant theoretical models for school motivation are the Achievement Goal Theory (AGT; Ames, 1992; Dweck, 1991; Maehr \& Midgley, 1996; Nicholls, 1984), the Future Time Perspective Theory (TFP; De Volder \& Lens, 1982; Nurmi, 1991; Nuttin \& Lens, 1985; Raynor \& Entin, 1982, Wigfield \& Eccles, 2002; Zimbardo \& Boyd, 1999), and the Self-Determination Theory (SDT; Deci \& Ryan, 1985, 2000, 2002; Ryan \& Deci, 2000, 2002).

The Achievement Goal Theory (Ames, 1992; Dweck, 1991; Maehr \& Midgley, 1996; Nicholls, 1984) proposed a qualitative and contextual theory of school motivation. Based on Elliot's $2 \times 2$ achievement goal framework (Elliot $\&$ McGregor, 2001), the AGT assumes that the masteryapproach goals, and to a lesser extent, the mastery-avoidance goals (Elliot \& Church, 1997; Pintrich, 2000) are associated to amotivation of high quality, the use of deep-level learning strategies and to the academic success. On the contrary, the performance-approach and performance-avoidance goals (Elliot \& Church, 1997; Pintrich, 2000) are associated to a motivation of low or even of bad quality, the use of surface-level learning strategies, and to low academic achievement(e.g., Elliot \& Church, 1997, Elliot \& McGregor, 2001). Research results on AGT were highly consensual regarding the positive and adaptive effects for learning, persistence and academic performance that resulted from a mastery goal orientation, and also regarding the negative and invalidating effects on the same indicators, that resulted from a performance-avoidance goal orientation (e.g., Elliot \& Church, 1997; Elliot \& Covington, 2001; Elliot \& McGregor, 2001; Harackiewicz, Barron, Tauer, Carter, \& Elliot, 2000, Midgley \& Urdan, 2001). The results were less consistent about the effects of performanceapproach goals, having been positively or negatively related to learning strategies and to the academic achievement (e.g., Elliot \& Moller, 2003; Harackiewicz et al., 2000; Matos, 2005, Matos, Lens, \& Vansteenkiste, 2007; Pintrich, 2000; Wolters, 2004).
The AGT also predicted that positive results on motivation, learning and academic achievement would be enhanced by learning-oriented classroom goal structures and undermined by performance-oriented classroom goal structures (Elliot, 1997; Pintrich, 2000). The research results provided adequate support for this hypothesis. Several studies found that students' perceptions of learning-oriented goal structures were associated to adaptive results on school motivation and academic achievement and that students' perceptions of performance-oriented goal structures were associated no negative and maladaptive results on those indicators (e.g., Ames \& Archer, 1988; Anderman \& Wolters, 2006; Graham \& Golan, 1991; Grolnick \& Ryan, 1987; Maehr \& Anderman, 1993; Maehr \& Midgley, 1996; Matos, Lens, \& Vansteenkiste, 2009; Midgley, 2002; Midgley \& Urdan, 2001; Wolters, 2004). Altogether, these data support the AGT's assumption that learning-oriented goals are of high motivational quality and, that the performance-oriented goals (including future goals, given their extrinsic nature) have a low/bad motivational quality, resulting in prejudice for intrinsic motivation and academic performance (Dweck, 1986; Pintrich \& Schunk, 1996).

This assumption received much criticism, mainly by the theorists of Future Time Perspective that considered it a reductionist view of school motivation (De Volder \& Lens, 1982; Nurmi, 1991; Nuttin \& Lens, 1985; Raynor \& Entin, 1982, Wigfield \& Eccles, 2002; Zimbardo \& Boyd, 1999). The PTF theorists proposed a quantitative model for the achievement motivation, assuming as a central premise that the strength or intensity of the total motivation to complete the achievement task was a function of the perceived instrumental value of that task to achieve future goals, regardless of their content (e.g., Creten, Lens, \& Simons, 2001; De Volder \& Lens, 1982; Husman \& Lens, 1999; Malka \& Covington, 2004; Simons, Dewite, \& Lens, 2003). In this view, the more goals the student had for the present task, the higher was their motivation to perform it. Thus, if we add extrinsic future goals to immediate intrinsic goals that would produce a stronger motivation on students to perform the task at hands, resulting not only from the pleasure of mastering it, but also from its perceived instrumental value to achieve future important goals.

In general, the research results have consistently supported the association between future time perspective and positive results for motivation, learning, satisfaction and academic performance (Harber, Zimbardo, \& Boyd, 2003; Horstmanshof \& Zimiat, 2007; Miller, DeBacker, \& Greene, 1999, Wigfield \& Eccles, 1992; Zaleski, 1987, 1994; Zimbardo \& Boyd, 1999). This effect was moderated by dispositional variables that affected the strength and depth to with which students set future goals, such as the extension of future time perspective and the affective attitude towards the future (e.g., DeVolder \& Lens, 1982; Lens, 1986; Nuttin \& Lens 1985; Paixão, 1996, 2004). 
More recently, the Self-Determination Theory (Deci \& Ryan, 1985, 2002; Ryan \& Deci, 2000, 2002) proposed a more conciliatory approach concerning students' motivation, based on the qualitative distinction between autonomous and controlled motivation for learning (DeBilde, Vansteenkiste, \& Lens, 2011; Deci \& Ryan, 2000). According to this perspective the extrinsic motivation can be of good or bad quality, depending on the degree of internalization of behavior regulations. The autonomous motivation (Deci, 1980; Deci \& Ryan, 1985; Ryan, Connell, \& Deci, 1985) is considered of good quality. It comprises intrinsically motivated students, that derive a spontaneous interest and pleasure out of learning and studying (DeBilde et al., 2011), but also students with well internalized forms of extrinsic motivation(with integrated or identified regulation), that engage in the academic tasks for its perceived utility to achieve self-endorsed goals, related to the implementation of important personal and professional projects (Deci \& Ryan, 2000).Conversely, the controlled motivation is assumed to be of bad quality. It is related to poorly internalized forms of extrinsic motivation (with external or introjected regulation) that regulate the students' behavior towards the attainment of privileges or rewards (e.g., promise of a car for good grades), to avoid external pressures or constraints (e.g., threats of punishment) or to comply with introjected controls (e.g., get good grades to avoid disappoint their parents and teachers).

In the school context, the research results made it consistently clear that autonomous motivation was of superior quality than controlled motivation. It was associated to students' lowest dropout rates, to a deep-level learning, a less superficial information processing, to higher academic results and to the experience of higher well-being (e.g., Lens \& Vansteenkiste, 2008; Mouratidis, Vansteenkiste, Lens, \& Sideridou, 2008; Reeve, Deci, \& Ryan, 2004; Vansteenkiste, Soenens, Verstuyf, \& Lens, 2009). These positive results were more expressive when the learning climate supported the students' autonomy, but they were undermined when the context was perceived as controlling (e.g., Black \& Deci, 2000; Lens, Paixão, \& Herrera, 2009; Reeve et al., 2004; Vansteenkiste et al., 2006; Vansteenkiste, Matos, Lens, \& Soenens, 2007; Vansteenkiste et al., 2004; Vansteenkiste et al., 2008).

Based on SDT's theoretical assumptions and inspiring results, some authors (e.g., DeBilde et al., 2011; Lens et al., 2009; Simons et al., 2003) analysed the impact of different types of instrumental motivation on student's intrinsic motivation and academic outcomes. The different typologies of instrumentality identified were obtained combining the relationship between the students' goal orientation for the current task and the future goals for which they were perceived as instrumental, with the four degrees of self-determination(internal versus external regulation). Using this framework, Husman and Lens (1999) distinguished between the endogenous vs exogenous types of instrumental motivation. More recently Simons et al. (2003) expanded this distinction, proposing a tripartite typology of perceived instrumentality. In the endogenousinternal type (EN-I), the learning task and future goals required the same capabilities and the activity was internally regulated. In the exogenous-internal (EX-I) and exogenousexternal (EX-E) types of instrumentality, the learning task and future goals required very different skills and the activity was either internally regulated (EX-I type) or externally regulated (EX-E type).The results showed that the instrumental motivation created in the endogenousinternal condition (EN-I), and, to a lesser extent, in the exogenous-internal condition (EX-I), produced the more adaptive results on academic motivation, task orientation and school achievement (Simons et al., 2003).

Based on these empirical findings, some authors (e.g., Lens et al., 2009) conclude for the need to revise, and ultimately abandon, the overly prudent attitude towards the extrinsic motivations and the exclusive promotion of intrinsic goals in the classroom. They believe that, if the professors promote intrinsic future goalswith instrumental value for students' future life and do it in an autonomous, volitional, practical and realistic way, positive and adaptive results on motivation, learning and achievement can be expected. This conclusion is a step forward in the direction of a paradigmatic turn in the study of academic motivation. It presents the advantage of stimulating the development for more conciliatory approaches into the field of school motivation. That, on our view, will necessarily require the development of more integrate comprehensive assessment tools, able to congregate constructs and measures that are derived from different conceptual frameworks ${ }^{1}$.

With this goal in mind, and following the PTF/SDT frameworks to school motivation, we developed the "School Motivation Questionnaire" (SMQ; Cordeiro \& Figueira, 2010). The SMQ is a self-report questionnaire aimed to measure the autonomous-controlled dimensions of students' goal orientations and perceived classroom goal structures, considering their content, temporality and behavior

\footnotetext{
1 One could argue that this goal may becontra-productiveor, at least redundantwith other methodological approaches that measure the same constructs in separate. Nonetheless, we do believe more integrative assessment tools have the advantage of establishingclearer conceptual frontiers between the constructs assessed. We find this aspect as determinant to overcome the conceptual confusion that has been frequently observed in the field of achievementmotivation, expressed by the diversity (and overlap) of concepts, theorized predictions and methodologies used (Perry, Turner \& Meyer, 2006).
} 
regulations. We intend to present here the structural model of scales and dimensions defined for the QME and report the exploratory results that attest the psychometric qualities of the SMQ, having in mind its future adaptation to the Portuguese population.

\section{Instrument}

The SMQ is a structured self-report questionnaire, composed by 101 closed questions. Four initial questions assess (a) the socio-demographic aspects of the students, namely the age, gender, school failures, type of school and type of education (Item 1 - personal data), (b) the discipline targeted on students' responses (Item 2: target discipline), and, (c) the information concerning the students' success at the discipline in the previous school term (Items 100/101 the grade I obtained during the previous school term was of $)^{2}$.

The following 97 questions measure the motivational processes of students, according to a structure of six dimensions and sixteen scales (see table 1).

The first dimension measures the students' perception of the classroom goal structures, in two different scales. The scale A1 (5 items: 7, 9, 37, 57, 70) assess the student's perception of a learning-oriented classroom goal structure (e.g., Item 7. The teacher of this subject really wants us to have pleasure in learning new things) and the scale A2 (4 Items: $6,16,20,41)$ assess the student's perception of a performance-oriented classroom goal structure (e.g., Item 41. In this subject, the teacher tells us how we are compared with other students).

The second dimension assesses the students' perception about the type of instrumental motivation that is promoted by the teacher in the classroom and the types of behavior regulations associated. The scale B1 (7 Items: 18, 64, 71, $82,88,94,99)$ assesses the perception of promoted exogenous instrumentality with external regulation (e.g., Item 71. In this subject, the teacher tells us it is important to have good grades to impress our parents). The scale B2 (7 Items: 34, 45, 51, 66, 74, 85, 97) measures the perception of promoted exogenous instrumentality with internal regulation (e.g., Item 66. The teacher tells us the grades we have on the subject are important achieve our future career goals). The scale B3 (5 Items: 10, 29, 32, 43, 60) assess the perception of promoted endogenous instrumentality with internal regulation (e.g., Item 29. The teacher of this subject considers that what we learn in class will be useful for other lessons that we have in the future).

The third dimension assesses the perception of the motivational profile of the teacher. The scale $\mathrm{C} 1$ (6 items: $24,39,42,59,76,80)$, measures the perceived autonomy support (e.g., Item 59. The teacher of this subject tries to understand the way I see things before suggesting a new way to have them) (see table 1).

The fourth dimension measures the students' goal orientation. The scale D1 (7 Items: 3, 8, 25, 28, 33, 36, 98) assesses the learning goal orientation to (e.g., Item 28 . In this subject, and for this academic year, one of my goals is to acquire many new skills and master them well), and the scale D2 (8 items: 12, 14, 19, 26, 31, 53, 63, 67) assess the performance goal orientation (e.g., Item 12. In this subject, one of my goals is to show others that I'm good at the classroom activities).

The fifth dimension measures the perceived instrumentality of school activities. The scale E1 (6 items: $62,65,72,78,87,93)$ assesses the exogenous instrumentality, with external regulation (e.g., Item 72. I try to have good grades in this subject to prove I'm smarter than most my colleagues). The scale E2 (6 items: 5, 22, $47,55,79,91)$ assesses the exogenous instrumentality, with internal regulation (e.g., Item 79. I have to pass this subject to achieve my academic goals). Finally, the scale E3 (7 Items: $40,61,69,77,84,90,96)$ assesses the endogenous instrumentality, with internal regulation (e.g., Item 84. In the future, I will use in other subjects, what I have learned from this subject).

The sixth dimension of the SMQ measures the use of learning strategies by students. The scale F1 (4 Items: 21, $23,49,92$ ) assesses the use of repetition strategies (e.g., Item 92 . When I study for this subject, I repeat to myself the topic several times). The scale F2 (6 items: $38,56,75$, $83,86,89)$ assesses the use of elaboration strategies (e.g., Item 56 . I try to connect the ideas of this subject with ideas from other subjects whenever possible). The scale F3 (4 Items: $15,35,44,52)$ measures the use of organization strategies (e.g., Item 52. I draw schemes, diagrams or simple tables to help me organize the topic.) The scale F4 (5 Items: $17,46,50,73,95)$ measures the critical thinking (e.g., Item 73. I consider the learned topic a starting point, but I try to develop my own opinion about it). Finally, the scale F5 (10 Items: $4,11,13,27,30,48,54,58,68,81)$ evaluates the use of meta cognitive strategies (e.g., Item 54. I try to change the way I study, in order to adapt myself to the requirements of this subject and the teaching style of the teacher).

Twelve out of the sixteen scales were adapted from three available instruments, selected on the basis of the psychometric qualities (see table 1).The first original instrument, entitled Perceptions of Instrumentality (PI; Husman, Derryberry, Crowson, \& Lomax, 2004), is a self-report scale, phrased in English and validated for the U.S. population. The PI consists of two subscales: Endogenous Instrumentality and Exogenous

2 We used the Portuguese classification system: qualitative values of $0-5$, for students in $9^{\text {th }}$ grade and quantitative values of $0-20$, for students in $12^{\text {th }}$ grade. 
Instrumentality. The Endogenous subscale consists of four items that ask about the utility of learning the course content for future goals $(\alpha=.73)$. The Exogenous instrumentality subscale consists of 4 items that ask if receiving a good grade or passing the course will help students achieve their future goals $(\alpha=.52)$. Students responded to both subscales on a five point Likert type response from 1 (strongly disagree) to 5 (strongly agree). The scores for each subscale are summed and the average values calculated. However, it is necessary to recode the scores of four of the eight items because they are negatively worded. The second instrument, named Cuestionário a Estudiantes, (CE; Matos, 2005) ${ }^{3}$ is a selfreport instrument written in Spanish and validated for the Peruvian population. It comprises 13 subscales that measure students' perceptions about their goal orientations and school culture, and also the teachers' perceptions about their goal orientation and instructional practices. For all the subscales considered, the alpha coefficients are above .60. Students' responses to the 63 items were punctuated on a on a five point Likert type response, from 1 (strongly disagree) to 5 (strongly agree). The $C E$ score is obtained calculating the average of individual scores. The third instrument, named Learning Climate Questionnaire (LCQ; Williams \& Deci, 1996) is a self-report questionnaire, written in English and validated for the U.S. population. The LCQ is composed by a single scale, consisting of 15 items in the long version, or 6 items in the short version (used in this study), that assess the degree to which students perceive the teacher as autonomy supportive $v s$ controlling $(\alpha>.90)$. Students responded on a seven point Likert type response from 1 (strongly disagree) to 7 (strongly agree). The score of the LCQ is obtained by calculating the average of individual scores. Highest scores

Table 1

Structure of Motivational Scales of the SMQ

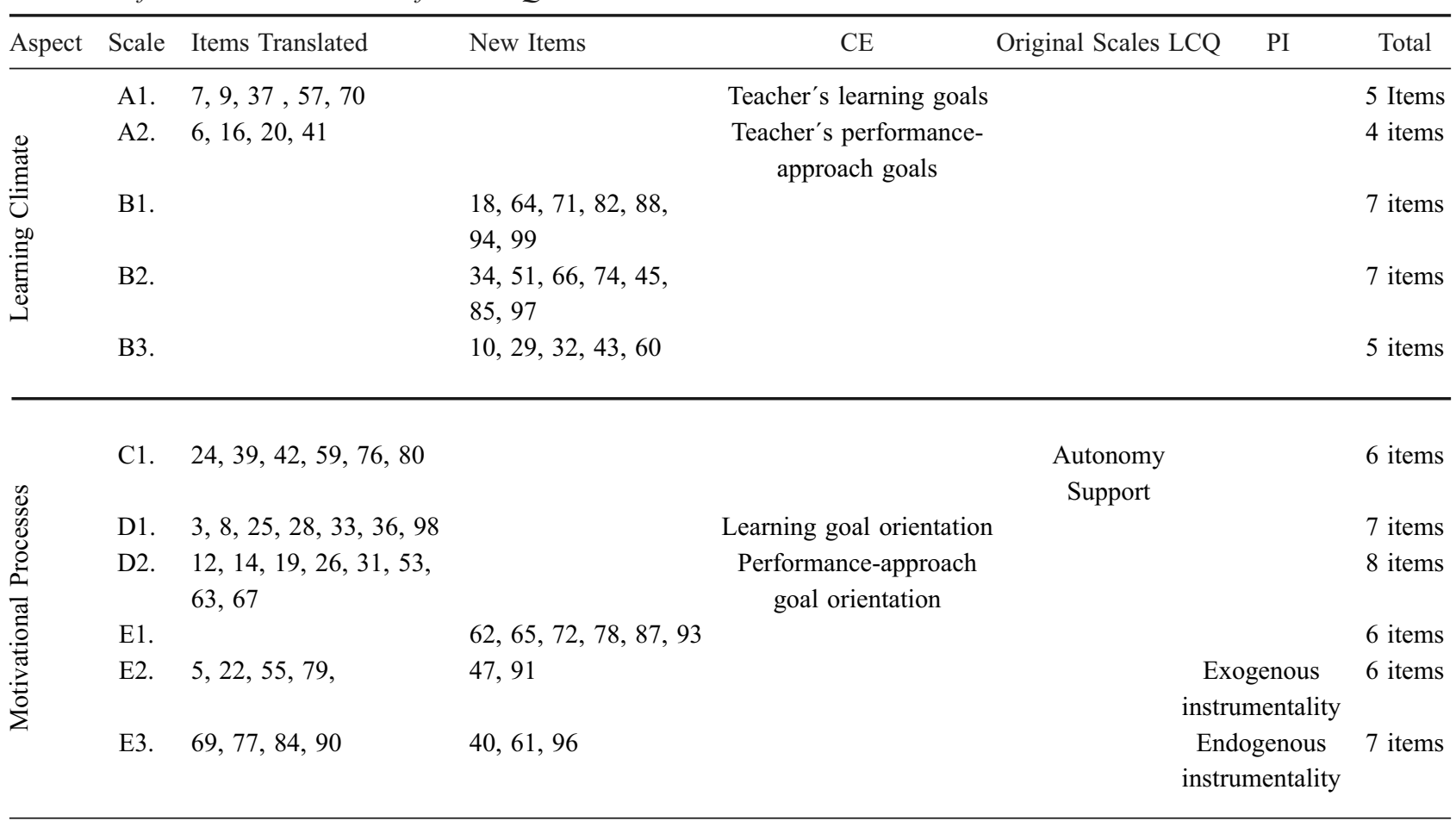

\begin{tabular}{|c|c|c|}
\hline w & F1. & $21,23,49,92$ \\
\hline & F2. & $38,56,75,83,86,89$ \\
\hline & F3. & $15,35,44,52$ \\
\hline & F4. & $17,46,50,73,95$ \\
\hline & F5. & $\begin{array}{l}4,11,13,27,30,48,54 \text {, Metacognitive strategies } \\
58,68,81\end{array}$ \\
\hline
\end{tabular}

Rehearsal strategies

Elaboration strategies

Organization strategies

Critical thinking

$58,68,81$
4 items

6 items

4 items

5 items

10 items

Total 97 Items

3 The CE is adapted from the Patterns of Adaptive Learning Scales (Pals;Midgley et al., 1997, 2000). 
express higher perceptions of teachers' autonomy support. For all the subscales (see table 1), we followed the translationback translation procedure (Duarte \& Rossier, 2008; Hambleton, 1994; Van de Vijver \& Hambleton, 1996). The LCQ and the PI were translated into Portuguese by a professional translator and retranslated into English by an independent translator. Then, the two back-translated documents were compared with the original version, (in order to determine the linguistic equivalence of items) and discussed the discrepancies between the two versions. This procedure was repeated until a final version was agreed (Figueira, 1994; Silva, 2010). The same translation- back translationprocedures were followed for the CE, but now involving Portuguese and Spanish speaking experts. For all the adapted instruments the necessary permits were obtained.

In addition to this procedure, four scales of the SMQ were created new, aimed to reinforce the tripartite nature of instrumental motivation, either perceived in the learning context (Scale B1, Items 18, 64, 71, 82, 88, 94, 99; Scale B2, Items 34, 45, 51, 66, 74, 85, 97; and Scale B3, items $10,29,32,43,60)$ or in the learning activities (Scale E1, items 62, 65, 72, 78, 87, 93).

Five additional items were also originally formulated to measure missing facets of the constructs (see table 1). In particular, the new items aimed to strengthen the behavioral regulation forms of the $P I$ items (scale E2: items 47 and 91; scale E3, items 40, 61, and 96) (for a review, see Cordeiro, 2010).

The SMQ was answered by the students, using a Likert type scoring system with five response categories, ranging from 1 (strongly disagree) to 5 (strongly agree). Eighty seven items were quoted in the forward direction (1-strongly disagree to 5 -strongly agree) and ten items (items 10,60 , $64,82,85,99,5,55,61,77)$ were quoted in the reverse way (5-strongly disagree to 1-strongly agree). The scores obtained for the SMQ are factorial scores and not global for academic motivation. The individual scores for each scale range between a minimum of 20 points in the Scale A2 and a maximum of 50 in the scale F5. We assume that the attribute is present when the individual score is higher than the average score calculated for each scale.

\section{Method}

\section{Participants}

The SMQ was administered to a convenience sample consisting of 485 students of the $9^{\text {th }}(N=248$ students $)$ and $12^{\text {th }}$ grade ( $N=237$ students) of both sexes ( $41.9 \%$ male, $N$ $=203$ and $58.1 \%$ female, $N=282$ ), aged between 13 and 24 years. For the entire sample, the average value for age was of 14.2 years $(22.1 \%)$ and the average value for standard deviation was of 1.1. The students surveyed were attending day school classes in public $(86.2 \%)$ and private Portuguese schools (13.8\%), during the academic year of 2009-2010. From the total sample, $48.9 \%(N=237)$ of the students were attending middle schools and $51.1 \%(N=248)$ were attending secondary schools. The districts sampledwere Aveiro, Castelo Branco, Évora, Portalegre and São Miguel, Azores.

\section{Procedures}

The psychometric analysis of the SMQ's properties began with a pilot study aimed to make a preliminary evaluation on the quality of the scale items translated, considering its readability and unambiguous comprehension. It was used a convenience sample $(N=29)$ of $9^{\text {th }}(N=17)$ and $12^{\text {th }}(N=12)$ grade students of both sexes, aged from 14 to 19 years, that were attending day school classes at the Basic School of Alter do Chão. The results led to the rephrasing of 4 items, but the number and order of the scale items stayed the same.

Once we got the final version of SMQ, and obtained the permissions from the General Directorate for Innovation and Curricular Development to administrate it in the Portuguese schools, we made formal contacts with the Executive Boards/Pedagogical Directorates of schools, asking them to collaborate in the study. They were sent an e-mail with a detailed description of the nature and goals of the research and the procedures for data collection, including the need to obtain informed consent from all the participants.

The SMQ was administered by the researcher in the classroom, using an online platform (www.surveymonkey. com/as/QME). All the participants received a token (password) for accessing the questionnaire. Prior to the filling of the questionnaire, the researcher read aloud the instructions to the students, emphasizing some aspects linked to the purpose and ethics of the study, such as the anonymity and confidentiality of data, the voluntary participation and the relevance of the study to understand and promote the students' motivation. This procedure intended to create optimal conditions to ensure the confidence and cooperation in the study, and minimize the effects of social desirability and any other forms of self-presentation. All students choose to participate in the study and validated the questionnaires without missing responses. That was an interpreted as an unambiguous signal that they were motivated enough to participate in the study in a responsible way.

\section{Results}

\section{Item analysis and the level of accuracy of the SMQ}

The descriptive statistics for all the 97 items expressed arithmetic mean values ranging from 2.15 to 3.72 , although most statistics were located around the mean value (3.30). The respondents used, for the 97 items, the five response 
possibilities. The standard deviation values lied between .963 and 1,345 . The corrected item-total correlations felt into the interval that ranged between .249 and .696 (see Appendix I). Only two items showed correlations lower than .30 (scale A1, item 7; scale D2, item 14). The values assigned to different items followed a slightly different distribution from the normal curve. However, the negative values for skewness and kurtosis (leptokurtic curve) detected did not significantly affect the validity of results obtained by the factor analysis (see Appendix I). The Cronbach's alpha coefficient for the total scale (97 items) was .97, showing very good values of internal consistency. This data suggest the good capacity for the SMQ to discriminate the subjects against the dimensions to be evaluated.

\section{Exploratory Factor Analysis of results}

The factorial validity of the SMQ was explored using the method of exploratory factor analysis (EFA; McIver \& Carmines, 1981) ${ }^{4}$. A first EFA, in principal components (PCA), using varimax orthogonal rotation ${ }^{5}$ extracted a solution of 17 components with eigenvalues-greater-than 1 , explaining $64.4 \%$ of the total variance of the questionnaire results (Tiensley \& Tiensley, 1987). The explained variance for each component was, respectively of $29.69 \%, 8.306 \%, 4.132 \%, 3.037 \%, 2.542 \%, 2.139 \%$, $1.793 \%, 1.611 \%, 1.485 \%, 1.391 \%, 1.268 \%, 1.236 \%$, $1.189 \%, 1.128 \%, 1.086 \%, 1.072 \%$ and $1.034 \%$.The exam of the scree-plot observed a sharp drop in the values of the Eigenvalues in the seventh factor, suggesting the retention of six factors. The eigenvalues obtained for the six components were, respectively of 28,$808 ; 8,306 ; 4,008$; $2.945 ; 2,466$, and 2,075 . The analysis of the correlation matrix with Varimax rotation, indicated that 26 items did not saturate at least at .40 with any factor, or they loaded in a factor without psychological meaning (items 5, 6, 8, $9,10,17,22,38,50,55,56,60,61,64,71,73,77,78,82$, $85,87,93,96,97,98,99)$. They were removed from the questionnaire.

A second EFA in Principal Axes and using Varimax rotation was done for the remaining 71 variables. Two necessary conditions to perform this analysis were attained. The Kaiser-Meyer-Olkin index for sampling adequacy $(K M O=.962)$ suggested that the data represented a homogeneous set of variables and the MSA indices $\left(\chi^{2}(2,485)=21,739,85, p<.001\right)$ indicated the existence of correlation between variables (Pestana \& Gageiro, 2008).
Nine factors were extracted with eigenvalues greater than one, explaining $54.015 \%$ of the total variance of the results. However, an in depth analysis of the factorial matrix made clear the data was distributed only in six factors, given that, no significant factorial loadings were observed from the seventh to the ninth factor. The six-factor structure explained $50,211 \%$ of the total variance of the items. The values of explained variance by extracted factor were of $16,397 \%$, $10,318 \%, 8,309 \%, 6,905 \%, 4,538 \%$ and $3,744 \%$. The exam of the screen-plot backed this six-factor structure. The eigenvalues obtained for the six factors were, respectively of $11,642,7,325 ; 5,900 ; 4,903 ; 3,222$, and 2,658. Finally, the analysis of the item-correlation/total scale-r, revealed positive correlations (higher than $.40 ; p<.01$ ) for 69 scale items with an interpretable factor: 24 items saturated in the first factor, 12 items in the second factor, 11 items in the third factor, 10 items in the fourth factor, 7 items in the fifth factor and, finally, 5 items in the sixth factor. Seven items presented complex factorial loadings, charging in more than one factor (items $25,28,36,40,69,84,90$ ). We decided to keep them in the factor they gained higher interpretability. Two other items presented important problems. The item 79 did not charge significantly in any interpretable factor and the item 20 did not load significantly on any factor. For this reasons, both items were removed from the questionnaire. The six factors presented high coefficients of internal consistency. It were obtained very good alpha coefficients for the factor 1 (.953), factor 2 (.904), factor 3 (.904) and factor 4 (.921), and good alpha coefficients for the factor $5(.863)$ and $6(.858)$. These coefficients provided statistical significance for the constituting variables of the SMQ (Figueira, 1994; Pestana \& Gageiro, 2008).Based on these results, we conclude that the six factor solution is the most valid and reliable structure to explain how the data is organized.

Following the recommendations of Sterling and Betz (1990) we ended our analysis with a psychological interpretation of the factors extracted. The first factor was identified as "Strategies". It assesses the use of learning strategies by students according to a structure of 24 items, organized in 5 scales. It comprises the rehearsal strategies scale (F1; items 21, 23, 49, 92), the elaboration strategies scale (F2; items $75,83,86,89$ ), the organization strategies scale (F3; items $15,35,44$, 52 ), the critical thinking scale (F4; items 46,95$)$ and the met cognitive strategies scale (F5; items 4, 11, 13, 27, $30,48,54,58,68,81$; See table 2).

\footnotetext{
4 We have reached the ratio of 5:1 subjects/variables (485 subjects and 97 items), a necessary and sufficient condition to perform an EFA at the results (Nunnally, 1978). Nevertheless it was not possible to obtain values for the matrix of Pearson product-moment inter-correlations, necessary to determine the "factors" of the SMQ (Silva, 2010).

5 Two criteria, commonly recommended in the literature, was followed to extract the number of factors: the Kaiser's eigenvaluegreater-than-one ruleand Cattell's Scree test (e.g., Figueira, 1994; Silva, 2010).
} 
Table 2

Factorial Model of the SMQ

\begin{tabular}{|c|c|c|c|c|c|}
\hline Structure of Scales & Items & Total & $\begin{array}{c}\text { Extracted } \\
\text { Factors }\end{array}$ & Items & Total \\
\hline A1. & $7,9,37,57,70$ & 5 items & & $70,7,37,57$ & \\
\hline $\mathrm{C} 1$. & $24,39,42,59,76,80$ & 6 Items & F4 & $24,39,42,59,76,80$ & 10 Items \\
\hline A2. & $6,16,20,41$ & 4 Items & & 16 & \\
\hline B1. & $18,64,71,82,88,94,99$ & 7 Items & $\mathrm{F} 2$ & $18,88,94$ & \\
\hline $\mathrm{B} 2$. & $34,51,66,74,45,85,97$ & 7 Items & & $34,45,51,66,74$ & \\
\hline B3. & $10,29,32,43,60$ & 5 Items & & $29,32,43$ & \\
\hline D1. & $3,8,25,28,33,36,98$ & 7 Items & F6 & $3,25,28,33,36$ & 5 Items \\
\hline D2. & $12,14,19,26,31,53,63,67$ & 8 Items & F3 & $63,67,12,53,14,19,26,31$ & 11 Items \\
\hline E1. & $62,65,72,78,87,93$ & 6 Items & & $62,65,72$ & \\
\hline E2. & $5,22,55,79,47,91$ & 6 Items & F5 & $47,91,93$ & 7 Items \\
\hline E3. & $69,77,84,90,40,61,96$ & 7 Items & & $69,84,90,40$ & \\
\hline F1. & $21,23,49,92$ & 4 Items & F1 & $21,23,49,92$, & 24 Items \\
\hline $\mathrm{F} 2$. & $38,56,75,83,86,89$ & 6 Items & & $75,83,86,89$ & \\
\hline F3. & $15,35,44,52$ & 4 Items & & $15,35,44,52$ & \\
\hline F4. & $17,46,50,73,95$ & 5 Items & & 46,95 & \\
\hline F5. & $4,11,13,27,30,48,54,58,68,81$ & 10 Items & & $4,11,13,27,30,48,54,58,68,81$ & \\
\hline
\end{tabular}

The second factor was named "Teacher Extrinsic Goals". It contains 12 items, organized in 4 scales that assess the students' perception of teacher's extrinsic motivations, including performance-oriented goal structures and futureoriented goal structures. Specific scales include a) the performance-oriented goals scale (A2; item 16), b) the exogenous instrumentality with external regulation scale (B1; items $18,88,94)$; c) the exogenous instrumentality with internal regulation scale (B2; items $34,45,51,66,74)$ and the endogenous instrumentality with internal regulation scale (B3; items 29, 32, 43).

The third factor was identified as "Student Extrinsic Goals, Externally Regulated". This construct addresses badly internalized forms of students' extrinsic motivation, including performance goal orientations and the perceived instrumentality of the learning activities to attain future goals that externally regulate the behavior. It contains 11 items organized in two scales, namely the performance oriented goals scale (D2; items 12, 14, 19, 26, 31, 53, 63, $67)$ and the exogenous instrumentality with external regulation scale (E1; items $62,65,72)$.

The fourth factor was called "Teacher Intrinsic Goals". It evaluates the students' perception of learning-oriented goal structures and the degree to which the teacher is perceived as autonomy supportive vs. controlling of the classroom dynamics. The 10 items it encompasses are distributed along 2 scales: the learning oriented goals scale (A1; items 7, 37, 57, 70) and the teacher autonomy support scale $(\mathrm{C} 1$; items $24,39,42,59,76,80)$.

The fifth factor was named "Student Extrinsic Goals, Internally Regulated". This construct addresses the well internalized (identified and integrated) forms of students' extrinsic motivation that internally regulate the behaviour (related to the personal or professional development). The construct is measured by 7 items in 2 scales: the exogenous instrumentality with internal regulation scale (E2; items 47, 91,93 ) and the endogenous instrumentality scale (E3; items $40,69,84,90)$.

The sixth factor was identified as "Student Intrinsic Goals". It measures the students' task goal orientation, implicated in the progressive acquisition of skills and mastery of learning tasks. It consists of 5 items, organized in a single scale, to know, the students' learning oriented goals scale (D1; items 3, 25, 28, 33, 36).

\section{Discussion and conclusion}

The exploratory studies performed on the factorial structure of the SMQ, supported its multi-dimensional structure, having discriminated six latent factors. The factor 1 was identified as "Strategies", the factor 2 as "Teacher Extrinsic Goals", the factor 3 as "Student Extrinsic Goals, Externally Regulated", the factor 4 as "Teacher Intrinsic Goals", the factor 5 as "Student Extrinsic Goals Internally Regulated", and the factor 6 as "Student Intrinsic Goals". The factorial model extracted provided support for, a) the distinction between the student motivational processes (goal orientations, perceived instrumentality and learning strategies) and the motivational processes of the learning environment (classroom goal structures and teacher autonomy support), b) the distinction of the intrinsic versus extrinsic content of 
goal orientations and of classroom goal structures, c) the distinction between learning and performance goalorientations (scales F6 and F3, respectively) and between learning and performance-oriented goal structures (scales F3 and F4, respectively), d) the tripartite structure of perceived instrumentality on students (scales E1, E2, and E3), and e) the distinction between motivational constructs and learning strategies. However the results failed to distinguish the five scale model defined to assess the learning strategies (scale F1, F2, F3, F4, F5), and also failed to distinguish the three types of instrumentality emphasized by the teacher (scales B1, B2 and B3). Also problematic were the patterns of interaction, not considered in the theoretical model, that were found between the constructs of performance goals and exogenous instrumentality with external regulation (scales F3 and F4) and between the concepts of learned-oriented goal structure and teacher autonomy support (scales A1 and C1). Overall, these limitations suggest the need for future research to a) provide conceptual refinements and more discriminative measures criteria of the tripartite nature of future-oriented goal structures, c) obtain data from a different categorization of learning strategies, based on the distinction between deep and surface learning strategies, d) make use of a representative sample, intended to validate the SMQ for the Portuguese population.

In general, the data matrix obtained attested the good psychometric qualities of SMQ. The six factor model obtained presented good or even very good estimates of construct validity. The constructs explained a significant variance of the item results (53.95\%), having all the items had positive and significant correlations with the factor where they saturate (at least .40). The QME also demonstrated to be a reliable instrument, showing good coefficients of internal consistency for the global scale (.97) and also for each factor, never below (.858; F6).In sum, there are strong indications to affirm the construct validity of the SMQ, and therefore to assert itself a reliable and robust instrument to assess the quality (or direction) of the achievement motivation of students in the school context. Nevertheless, the factor structure found should be interpreted with caution, since the data presented, although valid, only represent initial studies that explored the dimensionality of the instrument and not the final product in the process of validating the questionnaire.

\section{References}

Ames, C. (1992). Classrooms: Goals, structures, and student motivation. Journal of Educational Psychology, 84, 261-271. http://dx.doi.org/10.1037/0022-0663.84.3.261

Ames, C., \& Archer, J. (1988). Achievement goals in the classroom: Students' learning strategies and motivation processes. Journal of Educational Psychology, 80, 260-267. http://dx.doi.org/10.1037/0022-0663.80.3.260
Anderman, E. M., \& Wolters, C. (2006). Goals, values, and affect. In P. Alexander \& P. Winne (Eds.), Handbook of Educational Psychology (2 ${ }^{\text {nd }}$ Ed., pp. 369-390). Mahwah, NJ: Lawrence Erlbaum.

Black, A. E., \& Deci, E. L. (2000). The effects of instructors' autonomy support and students' autonomous motivation on learning organic chemistry: A self-determination theory perspective. Science Education, 84, 740-756. http://dx.doi.org/10.1002/1098-237X(200011)84:6<740::AIDSCE4>3.0.CO;2-3

Cordeiro, P. M. (2010). Construção e validação do Questionário de Motivação Escolar Para a população Portuguesa: Estudos exploratórios [Construction and validation of School Motivation Questionnaire for the Portuguese population: Exploratory studies]. (Unpublished doctoral dissertation). Universidade de Coimbra, Portugal.

Cordeiro, P. M. G., \& Figueira, A. P. C. (2010, July). Questionário de Motivação Escolar (QME) para a população Portuguesa: Arquitectura e qualidades psicométricas [School Motivation Questionnaire (SMQ) for the Portuguese population: Architecture and psychometric qualities]. Proceedings of I Seminário Internacional "Contributos da Psicologia em Contextos Educativos". Braga, Portugal: Universidade do Minho.

Creten, H., Lens, W., \& Simons, J. (2001). The role of perceived instrumentality in student motivation. In A. Efklides, J. Kuhl, \& R. M. Sorrentino (Eds.), Trends and prospects in motivation research (pp. 37-45). Dordrecht, The Netherlands: Kluwer Academic Publishers.

De Volder, M. L., \& Lens, W. (1982). Academic achievement and future time perspective as a cognitive-motivational concept. Journal of Personality and Social Psychology, 42, 566-571. http://dx.doi.org/10.1037/0022-3514.42.3.566

De Bilde, J., Vansteenkiste, M., \& Lens, W. (2011). Understanding the association between future time perspective and selfregulated learning through the lens of self-determination theory. Learning and Instruction, 21, 332-344. http://dx.doi.org/ 10.1016/j.learninstruc.2010.03.002

Deci, E. L. (1980). The psychology of self-determination. Lexington, MA: Hearth.

Deci, E. L., \& Ryan, R. M. (1985). Intrinsic motivation and selfdetermination in human behavior. New York, NY: Plenum Press.

Deci, E. L., \& Ryan, R. M. (2000). The "What" and "Why" of goal pursuits: Human needs and the self-determination of behavior. Psychological Inquiry, 11, 227-268. http://dx.doi.org/ 10.1207/S15327965PLI1104_01

Deci, E. L., \& Ryan, R. M. (2002). Handbook of self-determination research. Rochester, NY: University of Rochester Press.

Duarte, M. E., \& Rossier, J. (2008). Testing and assessment in an international context: Cross and multi-cultural issues. In J. A. Athanasou \& R. Van Esbroeck (Eds.), International handbook of career guidance. New York, NY: Springer.

Dweck, C. S. (1986). Motivational processes affecting learning. American Psychologist, 41, 1040-1048. http://dx.doi.org/ 10.1037/0003-066X.41.10.1040 
Dweck, C. S. (1991). Self-theories and goals: Their role in motivation, personality, and development. In R. A. Dienstbier (Ed.), Nebraska Symposium on Motivation: Vol. 38. Perspectives on motivation (pp. 199-235). Lincoln, NE: University of Nebraska Press.

Elliot, A. J. (1997). Integrating "classic" and "contemporary" approaches to achievement motivation: A hierarchical model of approach and avoidance achievement motivation. In P. Pintrich \& M. Maehr (Eds.), Advances in motivation and achievement (Vol. 10, pp. 143-179). Greenwich, CT: JAI Press.

Elliot, A. J., \& Church, M. A. (1997). A hierarchical model of approach and avoidance achievement motivation. Journal of Personality and Social Psychology, 72, 218-232. http://dx.doi.org/10.1037/0022-3514.72.1.218

Elliot, A. J., \& Covington, M. (2001). Approach and avoidance motivation. Educational Psychology Review, 13, 73-92. http://dx.doi.org/10.1023/A:1009009018235

Elliot, A. J., \& McGregor, H. A. (2001). A 2 x 2 Achievement goal framework. Journal of Personality and Social Psychology, 80, 501-519. http://dx.doi.org/10.1037/0022-3514.80.3.501

Elliot, A. J., \& Moller, A. C. (2003). Performance-approach goals: Good or bad forms of regulation. International Journal of Educational Research, 39, 339-356. http://dx.doi.org/10.1016/ j.ijer.2004.06.003

Figueira, A. P. C. (1994). Inventário de Estratégias de Estudo e de Aprendizagem (LASSI) [Learning and Study Strategies Inventory (LASSI)]. Weinstein \& Palmer, 1990. Estudos de adaptação e validação [Studies of adaptation and validation]. Psychologica, 12, 79-114.

Graham, S., \& Golan, S. (1991). Motivational influences on cognition: Task involvement, ego involvement, and depth of information processing. Journal of Educational Psychology, 83, 187-194. http://dx.doi.org/10.1037//0022-0663.83.2.187

Grolnick, W. S., \& Ryan, R. M. (1987). Autonomy in children's learning: An experimental and individual difference investigation. Journal of Personality and Social Psychology, 52, 890-898. http://dx.doi.org/10.1037/0022-3514.52.5.890

Hambleton, R. K. (1994). Diretrizes para adaptação de testes educacionais e psicológicos: Um relatório de progresso [Guidelines for adapting educational and psychological tests: A progress report]. Revista Europeia de Avaliação Psicológica, 10, 229-244.

Harber, K. D., Zimbardo, P. G., \& Boyd, J. N. (2003). Participantself-selection biases as a function of individual differences in time perspective. Basic and Applied Social Psychology, 25, 255-264. http://dx.doi.org/10.1207/S15324834 BASP2503 08

Harackiewicz, J. M., Barron, K. E., Tauer, J. M., Carter, S. M., \& Elliot, A. J. (2000). Short-term and long-term consequences of achievement goals predicting interest and performance over time. Journal of Educational Psychology, 92, 316-330. http://dx.doi.org/10.1037//0022-0663.92.2.316

Horstmanshof, L., \& Zimitat, C. (2007). Future time orientation predicts academic engagement among first-year university students. British Journal of Educational Psychology, 77, 703718. http://dx.doi.org/10.1348/000709906X160778

Husman, J., Derryberry, W. P., Crowson, H. M., \& Lomax, R. (2004). Instrumentality, task value, and intrinsic motivation: Making sense of their independent interdependence. Contemporary Educational Psychology, 29, 63-76. http://dx.doi.org/10.1016/ S0361-476X(03)00019-5

Husman, J., \& Lens, W. (1999).The role of the future in student motivation. Educational Psychologist, 34, 113-125. http://dx.doi.org/10.1207/s15326985ep3402_4

Lens, W. (1986). Future time perspective: A cognitive-motivational concept. In D.R. Brown \& J. Veroff (Eds.), Frontiers of motivational psychology (pp. 173-190). New York, NY: Springer-Verlag.

Lens, W., Paixão, M. P., \& Herrera, D. (2009). Instrumental motivation is extrinsic motivation: So what ???. Psychologica, $50,21-40$.

Lens W., \& Rand, P. (1997). Combining intrinsic goal orientation with Professional instrumentality/utility in student motivation. Polish Psychological Bulletin, 28, 103-123.

Lens, W., \& Vansteenkiste, M. (2008). Promoting self-regulated learning: A motivational analysis. In D. H. Schunk \& B. J. Zimmerman (Eds.), Motivational and self-regulated learning: Theory, research, and applications (pp. 141-168). Mahwah, NJ: Erlbaum.

Maehr, M. L., \& Anderman E. M. (1993). Reinventing schools for early adolescents: Emphasizing task goals. The Elementary School Journal, 93, 593-610. http://dx.doi.org/10.1086/461742

Maehr, M. L., \& Midgley, C. (1996). Transforming school cultures. Boulder, CO: Westview Press.

Malka, A., \& Covington, M. V. (2004). Perceiving school performance as instrumental to future goal attainment: Effects on graded performance. Contemporary Educational Psychology, 30, 60-80.

Matos, L. (2005). School culture, teacher's and student's achievement goals as communicating vessels. A study in Peruvian Secondary schools. (Unpublished doctoral dissertation). University of Leuven, Belgium.

Matos, L., Lens, W., \& Vansteenkiste, M. (2007). Achievement goals, learning strategies and language achievement among Peruvian high school students. Psychologica Belgica, 47, 51-70.

Matos, L., Lens, W., \& Vansteenkiste, M. (2009). School culture matters for teacher's and student's achievement goals. In A. Kaplan, S. Karabenick, \& E. De Groot (Eds.), Culture, self, and motivation: Essays in honor of Martin L. Maehr. Charlotte, NC: Information Age.

McIver, J. P., \& Carmines, E. G. (1981).Unidimensional scaling. Thousand Oaks, CA: Sage.

Midgley, C. (Ed.).(2002). Goals, goal structures, and patterns of adaptive learning. Mahwah, NJ: Erlbaum.

Midgley, C., \& Urdan, T. (2001). Academic self-handicapping and achievement goals: A further examination. Contemporary Educational Psychology, 26, 61-75. http://dx.doi.org/10.1006/ ceps.2000.1041 
Miller, R. B., DeBacker, T. K., \& Greene, B. A. (1999). Perceived instrumentality and academics: The link to task valuing. Journal of Instructional Psychology, 26, 250-260.

Mouratidis, A., Vansteenkiste, M., Lens, W., \& Sideridis, G. (2008). The motivating role of positive feedback in sport and physical education: Evidence for a motivational model. Journal of Sport \& Exercise Psychology, 30, 240-268.

Nicholls, J. G. (1984). Achievement motivation: Conceptions of ability, subjective experience, task choice, and performance. Psychological Review, 91, 328-346. http://dx.doi.org/10.1037//0033-295X.91.3.328

Nunnally, J. C. (1978). Psychometric theory (2 ${ }^{\text {nd }}$ Ed.). New York, NY: McGraw Hill.

Nurmi, J. E. (1991). How do adolescents see their future? A review of the development of future orientation and planning. Developmental Review, 11, 1-59. http://dx.doi.org/10.1016/02732297(91)90002-6

Nuttin, J., \& Lens, W. (1985). Future time perspective and motivation: Theory and research method. Hillsdale, NJ: Erlbaum.

Paixão, M. P. (1996). Organização da vivência do futuro $e$ comportamento de planificação. compreensão dos processos motivacionais e cognitivos na elaboração e avaliação de projectos pessoais [Organization of behavior and experience of the future planning. Understanding the motivation and cognitive processes in the development and evaluation of personal projects]. (Unpublished doctoral dissertation). Universidade de Coimbra, Portugal.

Paixão, M. P. (2004). A avaliação dos factores e processos motivacionais na orientação vocacional [The motivational factors and processes evaluation in the vocational orientation]. In L. M. Leitão (Ed.), Avaliação psicológica em orientação escolar e Profissional [Psychological assessment in educationaland vocational guidance]. (pp. 387-425). Coimbra, Portugal: Quarteto Editora.

Pestana, M., \& Gageiro, J. (2008). Análise de dados para ciências sociais: Acomplementaridade do SPSS [Analysisof data forsocial sciences: the complementarity of the SPSS] ( $5^{\text {th }} \mathrm{Ed}$.). Lisboa, Portugal: Edições Sílabo.

Perry, N., Turner, J. C., \& Meyer, D. K. (2006). Student engagement in the classroom. In P. Alexander \& P. Winne (Eds.), Handbook of Educational Psychology (pp.327-348). Mahwah, NJ: Erlbaum.

Pintrich, P. R. (2000). An achievement goal theory perspective on issues in motivation terminology, theory, and research. Contemporary Educational Psychology, 25, 92-104. http://dx.doi.org/10.1006/ceps.1999.1017

Pintrich, P. R., \& Schunk, D. H. (1996). Motivation in education: Theory, research and application. Englewood Cliffs, NJ: Prentice Hall.

Raynor, J. O., \& Entin, E. E. (1982). Theory and research on future orientation and achievement motivation. In J. O. Raynor \& E. E. Entin (Eds.), Motivation, career striving, and aging (pp. 13-82). New York, NY: Hemisphere Publishing.

Reeve, J., Deci, E. L., \& Ryan, R. M. (2004). Self-determination theory: A dialectical framework for understanding sociocultural influences on student motivation. In D. M. McInerney \& S. Van Etten (Eds.), Big theories revisited: Research on sociocultural influences on motivation and learning (Vol. 4, pp. 31-60). Greenwich, CT: Information Age Publishing.

Reeve, J., Jang, H., Carrell, D., Jeon, S., \& Barch, J. (2004). Enhancing students' engagement by increasing teachers' autonomy support. Motivation and Emotion, 2, 147-169. http://dx.doi.org/10.1023/B:MOEM.0000032312.95499.6f

Ryan, R. M., Connell, J. P., \& Deci, E. L. (1985). A motivational analysis of self-determination and self-regulation in education. In C. Ames \& R. E. Ames (Eds.), Research on motivation in education: The classroom milieu (pp. 13-51). New York, NY: Academic.

Ryan, R. M., \& Deci, E. L. (2000). Self-determination theory and the facilitation of intrinsic motivation, social development, and well-being. American Psychologist, 55, 68-78. http://dx.doi.org/10.1037//0003-066X.55.1.68

Ryan, R. M., \& Deci, E. L. (2002). An overview of selfdetermination theory: An organismic-dialectical perspective. In E. L. Deci \& R. M. Ryan (Eds.), Handbook of selfdetermination research (pp. 3-33). Rochester, NY: University of Rochester Press.

Silva, J. M. T. (2010). Avaliação do "Medo do Comprometimento" no Comportamento Vocacional [Evaluation of the "Fear of Commitment" in Vocational Behavior]. Psicologia, Educação e Cultura, 14, 59-78.

Simons, J., Dewitte, S., \& Lens, W. (2003). "Don’t do it for me, do it for yourself." Stressing the personal relevance enhances motivation in physical education. Journal of Sport Exercise Psychology, 25, 145-160.

Serling, D. A., \& Betz, N. E. (1990). Development and evaluation of a measure of fear of commitment. Journal of Counseling Psychology, 37, 91-97. http://dx.doi.org/10.1037//00220167.37.1.91

Tinsley, H. E. A., \& Tinsley, D. J. (1987). Uses of factor analysis in counseling psychology research. Journal of Counseling Psychology, 34, 414-424. http://dx.doi.org/10.1037//00220167.34.4.414

Van de Vijver, F. J. R., \& Hambleton, R. K. (1996).Translating tests: Some practical guide lines. European Psychologist, 1, 89-99. http://dx.doi.org/10.1027/1016-9040.1.2.89

Vansteenkiste, M., Lens, W., \& Deci, E. L. (2006). Intrinsic versus extrinsic goal contents in self-determination theory: Another look at the quality of academic motivation. Educational Psychologist, 41, 19-31. http://dx.doi.org/10.1207/s15326985 ep4101_4

Vansteenkiste, M., Matos, L., Lens, W., \& Soenens, B. (2007). Understanding the impact of intrinsic versus extrinsic goal framing on exercise performance: The conflicting role of task and ego involvement. Psychology of Sport and Exercise, 8, 771-794. http://dx.doi.org/10.1016/j.psychsport.2006.04.006

Vansteenkiste, M., Simons, J., Lens, W., Soenens, B., Matos, L., \& Lacante, M. (2004). Less is sometimes more: Goal content matters. Journal of Educational Psychology, 96, 755-764. http://dx.doi.org/10.1037/0022-0663.96.4.755 
Vansteenkiste, M., Soenens, B., Verstuyf, J., \& Lens, W. (2009). 'What is the usefulness of your schoolwork?' The differential effects of intrinsic and extrinsic goal framing on optimal learning. Theory and Research in Education, 7, 155-163. http://dx.doi.org/10.1177/1477878509104320

Vansteenkiste, M., Timmermans, T., Lens, W., Soenens, B., \& Van den Broeck, A. (2008). Does extrinsic goal framing enhance extrinsic goal oriented individuals' learning and performance? An experimental test of the match-perspective vs. selfdetermination theory. Journal of Educational Psychology, 100, 387-397. http://dx.doi.org/10.1037/0022-0663.100.2.387

Wigfield, A., \& Eccles, J. S. (1992). The development of achievement task values: A theoretical analysis. Developmental Review, 12, 265-310. http://dx.doi.org/10.1016/02732297(92)90011-P

Wigfield, A., \& Eccles, J. S. (Eds.) (2002). Development of achievement motivation. San Diego, CA: Academic Press.

Williams G. C., \& Deci E. L. (1996). Internalization of biopsychosocial values by medical students: A test of selfdetermination theory. Journal of Personality and Social
Psychology, 70, 767-779. http://dx.doi.org/10.1037/00223514.70.4.767

Wolters, C. A. (2004). Advancing achievement goal theory: Using goal structures and goal orientations to predict students' motivation, cognition, and achievement. Journal of Educational Psychology, 96, 236-250. http://dx.doi.org/10.1037/00220663.96.2.236

Zaleski, Z. (1987). Behavioral effects of self-set goals for different time ranges. International Journal of Psychology, 22, 17-38. http://dx.doi.org/10.1080/00207598708246765

Zaleski, Z. (Ed.) (1994). Psychology of future orientation. Lublin, Poland: Towarzystwo Naukowe KUL.

Zimbardo, P. G., \& Boyd, J. N. (1999). Putting time in perspective: A valid, reliable individual differences metric. Journal of Personality and Social Psychology, 77, 1271-1288. http://dx.doi.org/10.1037/0022-3514.77.6.1271

Received March 1, 2011 Revision received October 30, 2011 Accepted December 28, 2011 
ANNEX I

Descriptive Statistics

\begin{tabular}{|c|c|c|c|c|c|c|c|c|c|c|}
\hline & \multirow{2}{*}{$\begin{array}{c}\mathrm{N} \\
\text { Statistic }\end{array}$} & \multirow{2}{*}{$\begin{array}{l}\text { Minimum } \\
\text { Statistic }\end{array}$} & \multirow{2}{*}{$\begin{array}{l}\text { Maximum } \\
\text { Statistic }\end{array}$} & \multicolumn{2}{|c|}{ Mean } & \multirow{2}{*}{$\begin{array}{l}\text { Std. Deviation } \\
\text { Statistic }\end{array}$} & \multicolumn{2}{|c|}{ Skewness } & \multicolumn{2}{|c|}{ Kurtosis } \\
\hline & & & & Statistic & Std. Error & & Statistic & Std. Error & Statistic & Std. Error \\
\hline p70 & 485 & 1 & 5 & 3,42 &, 046 & 1,006 &,- 350 & ,111 &,- 087 & ,221 \\
\hline p7 & 485 & 1 & 5 & 3,62 & 048 & 1,054 &,- 528 & ,111 &,- 154 & ,221 \\
\hline p57 & 485 & 1 & 5 & 3,59 &, 048 & 1,063 &,- 449 &, 111 &,- 270 &, 221 \\
\hline p37 & 485 & 1 & 5 & 3,73 &, 044 &, 963 &,- 570 & ,111 &, 102 & 221 \\
\hline p16 & 485 & 1 & 5 & 3,51 & 050 & 1,107 &,- 389 & , 111 &,- 357 & 221 \\
\hline p20 & 485 & 1 & 5 & 2,95 &, 061 & 1,345 &, 053 & ,111 & $-1,109$ & 221 \\
\hline p88 & 485 & 1 & 5 & 3,40 &, 052 & 1,145 &,- 303 & ,111 &,- 570 & 221 \\
\hline p94 & 485 & 1 & 5 & 3,33 & 053 & 1,165 &,- 375 & ,111 &,- 550 & 221 \\
\hline p34 & 485 & 1 & 5 & 3,48 & 050 & 1,101 &,- 519 & , 111 &,- 194 & 221 \\
\hline p45 & 485 & 1 & 5 & 3,66 &, 046 & 1,013 &,- 578 & ,111 &, 093 & 221 \\
\hline p51 & 485 & 1 & 5 & 3,38 & 051 & 1,119 &,- 367 & , 111 &,- 477 & 221 \\
\hline p66 & 485 & 1 & 5 & 3,64 &, 047 & 1,028 &,- 447 &, 111 &,- 241 & 221 \\
\hline p74 & 485 & 1 & 5 & 3,49 & 051 & 1,113 &,- 423 & , 111 &,- 417 & 221 \\
\hline p18 & 485 & 1 & 5 & 3,72 & 048 & 1,066 &,- 717 &, 111 &, 171 & 221 \\
\hline p29 & 485 & 1 & 5 & 3,66 & 047 & 1,026 &,- 511 & ,111 &,- 082 & 221 \\
\hline p32 & 485 & 1 & 5 & 3,71 &, 047 & 1,025 &,- 540 & ,111 &,- 060 &, 221 \\
\hline p43 & 485 & 1 & 5 & 3,61 &, 047 & 1,032 &,- 604 &, 111 &, 170 & 221 \\
\hline p93 & 485 & 1 & 5 & 3,39 & 052 & 1,146 &,- 374 &, 111 &,- 522 & 221 \\
\hline p47 & 485 & 1 & 5 & 3,44 &, 049 & 1,089 &,- 418 & ,111 &,- 215 & 221 \\
\hline p79 & 485 & 1 & 5 & 3,48 & 052 & 1,136 &,- 459 &, 111 &,- 417 & 221 \\
\hline p91 & 485 & 1 & 5 & 3,48 & 048 & 1,065 &,- 582 & ,111 &, 056 & 221 \\
\hline p40 & 485 & 1 & 5 & 3,69 & 049 & 1,078 &,- 650 & ,111 &,- 065 & 221 \\
\hline p69 & 485 & 1 & 5 & 3,51 & 048 & 1,063 &,- 408 & ,111 &,- 227 & 221 \\
\hline p84 & 485 & 1 & 5 & 3,45 & 048 & 1,064 &,- 363 & ,111 &,- 328 & 221 \\
\hline p90 & 485 & 1 & 5 & 3,50 & 051 & 1,131 &,- 504 & ,111 &,- 321 & 221 \\
\hline p12 & 485 & 1 & 5 & 2,97 & 055 & 1,211 &,- 057 & ,111 &,- 818 & 221 \\
\hline p14 & 485 & 1 & 5 & 2,15 &, 056 & 1,222 &, 763 & ,111 &,- 502 & 221 \\
\hline p26 & 485 & 1 & 5 & 2,45 &, 054 & 1,182 & 405 &, 111 &,- 714 & 221 \\
\hline p31 & 485 & 1 & 5 & 2,22 & 055 & 1,210 & ,682 & ,111 &,- 543 & 221 \\
\hline p53 & 485 & 1 & 5 & 2,98 &, 057 & 1,264 &,- 007 & ,111 &,- 910 & 221 \\
\hline p63 & 485 & 1 & 5 & 2,67 & 055 & 1,217 &, 204 & ,111 &,- 834 & 221 \\
\hline p67 & 485 & 1 & 5 & 2,62 &, 059 & 1,295 & 242 &, 111 & $-1,010$ & 221 \\
\hline p72 & 485 & 1 & 5 & 2,43 & 056 & 1,241 & 455 &, 111 &,- 785 & 221 \\
\hline p19 & 485 & 1 & 5 & 3,26 &, 054 & 1,193 &,- 203 &, 111 &,- 803 & 221 \\
\hline p62 & 485 & 1 & 5 & 3,08 & 055 & 1,210 &,- 193 &, 111 &,- 779 & 221 \\
\hline p65 & 485 & 1 & 5 & 3,30 &, 053 & 1,173 &,- 279 &, 111 &,- 601 &, 221 \\
\hline p76 & 485 & 1 & 5 & 3,25 &, 048 & 1,061 &,- 235 &, 111 &,- 311 & 221 \\
\hline p80 & 485 & 1 & 5 & 3,27 & 049 & 1,088 &,- 263 &, 111 &,- 408 & 221 \\
\hline p24 & 485 & 1 & 5 & 3,45 & 045 &, 990 &,- 289 &, 111 &,- 156 & 221 \\
\hline p39 & 485 & 1 & 5 & 3,34 &, 051 & 1,113 &,- 353 &, 111 &,- 451 & 221 \\
\hline p42 & 485 & 1 & 5 & 3,21 &, 046 & 1,017 &,- 182 &, 111 &,- 113 & 221 \\
\hline p59 & 485 & 1 & 5 & 3,27 & 047 & 1,043 &,- 260 &, 111 &,- 179 & 221 \\
\hline p3 & 485 & 1 & 5 & 3,80 & 045 & ,992 &,- 747 &, 111 &, 323 &, 221 \\
\hline p25 & 485 & 1 & 5 & 3,48 & 049 & 1,077 &,- 448 &, 111 &,- 204 & 221 \\
\hline p28 & 485 & 1 & 5 & 3,62 &, 046 & 1,016 &,- 437 &, 111 &,- 144 & 221 \\
\hline p33 & 485 & 1 & 5 & 3,70 &, 046 & 1,018 &,- 590 &, 111 &, 014 & 221 \\
\hline p36 & 485 & 1 & 5 & 3,66 & 049 & 1,082 &,- 584 &, 111 &,- 166 & 221 \\
\hline p92 & 485 & 1 & 5 & 3,35 &, 052 & 1,153 &,- 357 &, 111 &,- 519 & 221 \\
\hline p49 & 485 & 1 & 5 & 3,41 &, 050 & 1,105 &,- 495 & ,111 &,- 240 & 221 \\
\hline p23 & 485 & 1 & 5 & 3,03 & 055 & 1,200 &,- 078 &, 111 &,- 837 & 221 \\
\hline p21 & 485 & 1 & 5 & 2,98 &, 052 & 1,136 &,- 091 &, 111 &,- 617 & 221 \\
\hline p75 & 485 & 1 & 5 & 3,34 &, 050 & 1,109 &,- 428 &, 111 &,- 340 & 221 \\
\hline p83 & 485 & 1 & 5 & 3,25 &, 051 & 1,117 &,- 294 &, 111 &,- 515 & 221 \\
\hline p86 & 485 & 1 & 5 & 3,37 &, 047 & 1,026 &,- 324 &, 111 &,- 078 & 221 \\
\hline p89 & 485 & 1 & 5 & 3,38 & 045 &, 990 &,- 389 &, 111 &,- 021 & 221 \\
\hline p44 & 485 & 1 & 5 & 3,39 & 051 & 1,122 &,- 436 &, 111 &,- 412 & 221 \\
\hline p15 & 485 & 1 & 5 & 3,34 & 052 & 1,153 &,- 400 &, 111 &,- 482 & 221 \\
\hline p52 & 485 & 1 & 5 & 2,91 & 053 & 1,157 &,- 039 & ,111 &,- 738 & 221 \\
\hline p35 & 485 & 1 & 5 & 3,40 & 052 & 1,145 &,- 453 & ,111 &,- 361 & ,221 \\
\hline p46 & 485 & 1 & 5 & 3,20 & ,046 & 1,016 &,- 195 & ,111 &,- 150 & ,221 \\
\hline $\mathrm{p} 4$ & 485 & 1 & 5 & 3,17 & 054 & 1,189 &,- 249 & ,111 &,- 748 & 221 \\
\hline p68 & 485 & 1 & 5 & 3,51 & 047 & 1,032 &,- 506 & ,111 &, 034 & 221 \\
\hline p48 & 485 & 1 & 5 & 3,20 & 050 & 1,097 &,- 200 &, 111 &,- 438 & 221 \\
\hline p13 & 485 & 1 & 5 & 3,28 & ,049 & 1,077 &,- 397 & ,111 &,- 336 & ,221 \\
\hline p30 & 485 & 1 & 5 & 3,29 &, 050 & 1,100 &,- 315 & ,111 &,- 403 & 221 \\
\hline p54 & 485 & 1 & 5 & 3,19 & 049 & 1,077 &,- 299 & ,111 &,- 344 & ,221 \\
\hline p27 & 485 & 1 & 5 & 3,36 & 048 & 1,059 &,- 426 & ,111 &,- 204 & 221 \\
\hline p11 & 485 & 1 & 5 & 3,44 & 049 & 1,087 &,- 527 & ,111 &,- 115 & ,221 \\
\hline p81 & 485 & 1 & 5 & 3,15 & 047 & 1,045 &,- 123 & ,111 &,- 341 & ,221 \\
\hline p58 & 485 & 1 & 5 & 3,36 &, 047 & 1,045 &,- 326 & ,111 &,- 232 & ,221 \\
\hline p95 & 485 & 1 & 5 & 3,22 &, 047 & 1,029 &,- 324 & ,111 &,- 188 & ,221 \\
\hline & & & & & id $\mathrm{N}$ (listwis & se) 485 & & & & \\
\hline
\end{tabular}




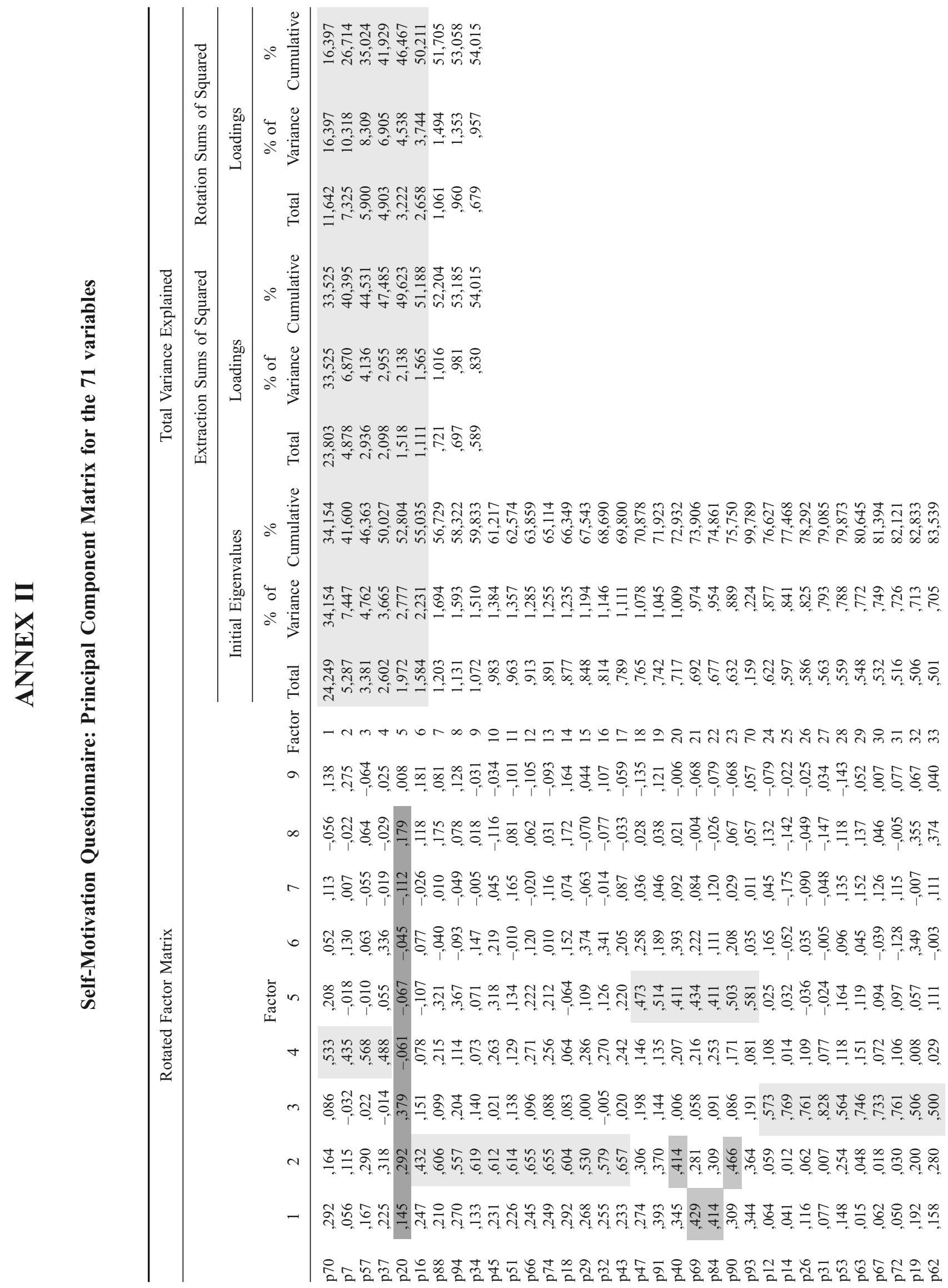




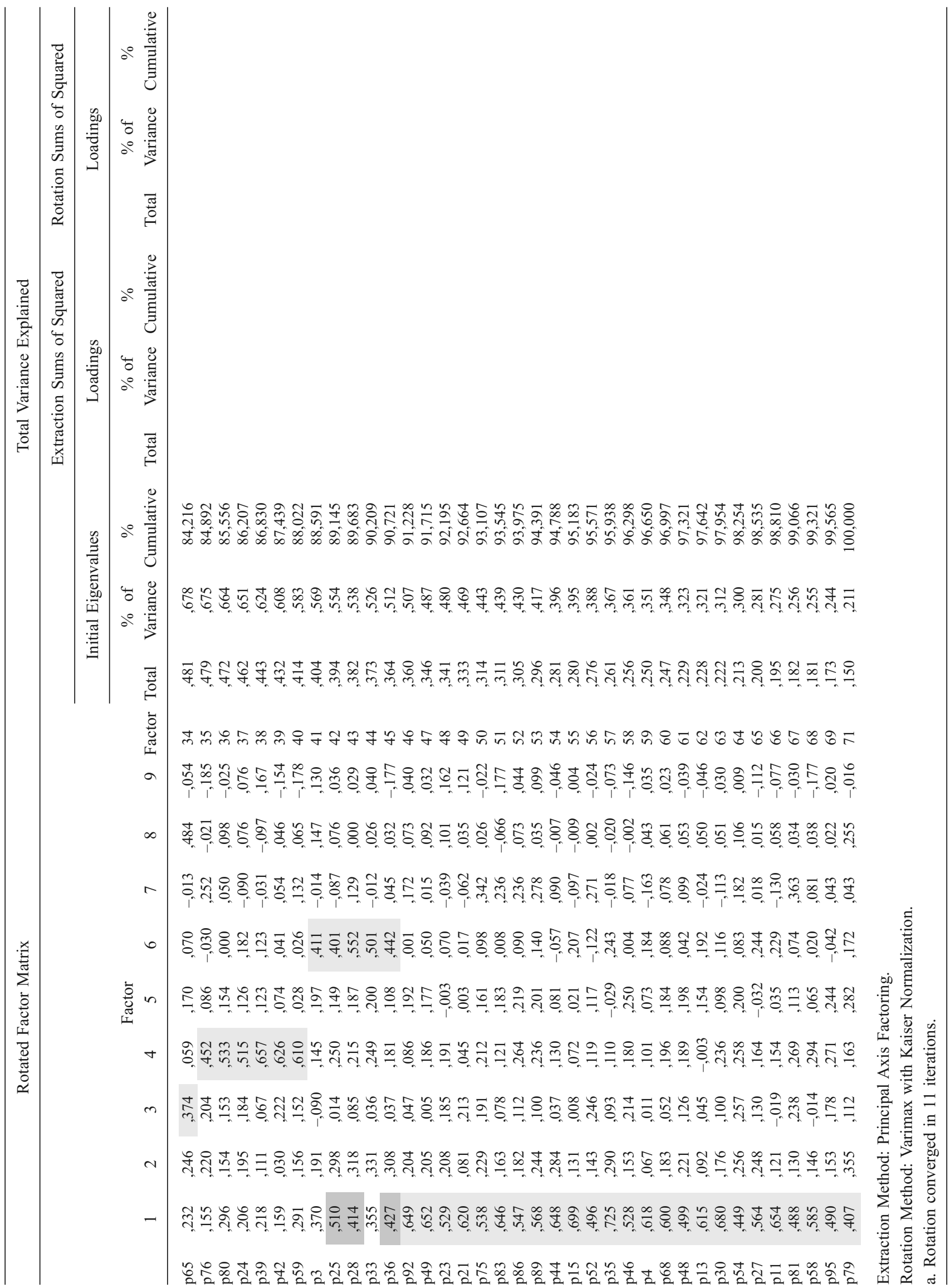

